\title{
Morphological description of Cyclotella atomus var. marina (Bacillariophyceae): newly reported in Korean waters
}

\author{
Mi Hee Chung ${ }^{1}$, Won Duk Yoon ${ }^{1}$ and Joon-Baek Lee ${ }^{2, *}$ \\ ${ }^{1}$ National Fisheries Research and Development Institute, Busan 619-705, Korea \\ ${ }^{2}$ Department of Earth and Marine Sciences, Marine and Environmental Research Institute, Jeju National University, Jeju \\ 690-756, Korea
}

A variety of Cyclotella atomus were discovered among the epiphytic diatoms on eelgrass (Zostera marina L.) in Korean waters. Cyclotella atomus var. marina has a flat and disc-shaped valve, and is clearly differentiated into a striate marginal zone and a smooth central zone. The valves have a very small diameter ranging from 3.1-3.4 $\mu \mathrm{m}$. This small diatom does not have any central ornamentation. The marginal striate zone has numerous granules toward the mantle. The valves have five or six marginal fultoportulae with two satellite pores and a single marginal rimoportula.

Key Words: Cyclotella; Cyclotella atomus var. marina; diatom; eelgrass; epiphytic

\section{INTRODUCTION}

Genus Cyclotella comprises a large complex of centric diatoms, which have been divided into different groups (Håkansson 2002). This genus was first introduced by Kützing (1833) as a subgenus of Frustulia Ag., which included one species, Frustulia operculata Ag. Brébisson (1838) adopted the Cyclotella group of Kützing as a new genus, which included two species: Cyclotella ovalis and C. operculata. However, no generitype was designated by Brébisson. C. operculata, the monotype of the subgenus, automatically became the generitype of the genus. Cyclotella (Kütz.) Brébisson was predominantly a freshwater genus in the family Stephanodiscaceae Makarova and highly diverse with more than 100 species (van Landingham 1969).

Cyclotella has been widely reported in various habitats including terrestrial fossil species, freshwater species, brackish or marine water species, and even attached species on phytoplankton and macrophyte (Sullivan 1982, Chang and Steinberg 1988, Håkansson et al. 1993, Hasle and Syvertsen 1997). However, description of Cyclotella attached to seagrass has been rare.

Some taxonomical studies on Cyclotella have been carried out in Korea (Lee and Lee 1988, Lee et al. 1994, Lee et al. 1995b, Cho 1996). Several Cyclotella species, such as C. badanica, C. comta, C. meneghiniana, C. stelligera, C. striata, C. striata var. ambigua, and C. stylorum, were reported as the benthic diatom from the coastal areas (Choi 1990) and 15 Cyclotella species were reported as the plankters from the freshwater, brackish and marine waters of Korea (Lee et al. 1995b).

Presently, we describe the newly reported variety $C y$ clotella atomus var. marina in Korean waters based on scanning electron microscopy (SEM) observation.

\section{MATERIALS AND METHODS}

Eelgrass (Zostera marina L.) samples were collected (c) This is an Open Access article distributed under the terms of the Creative Commons Attribution Non-Commercial License (http://creativecommons.org/licenses/by-nc/3.0/) which permits unrestricted non-commercial use, distribution, and reproduction in any medium, provided the original work is properly cited.
Received 15 March 2010, Accepted 3 May 2010

"Corresponding Author

E-mail: jblee@jejunu.ac.kr

Tel: +82-64-754-3435, Fax: +82-64-725-2461 


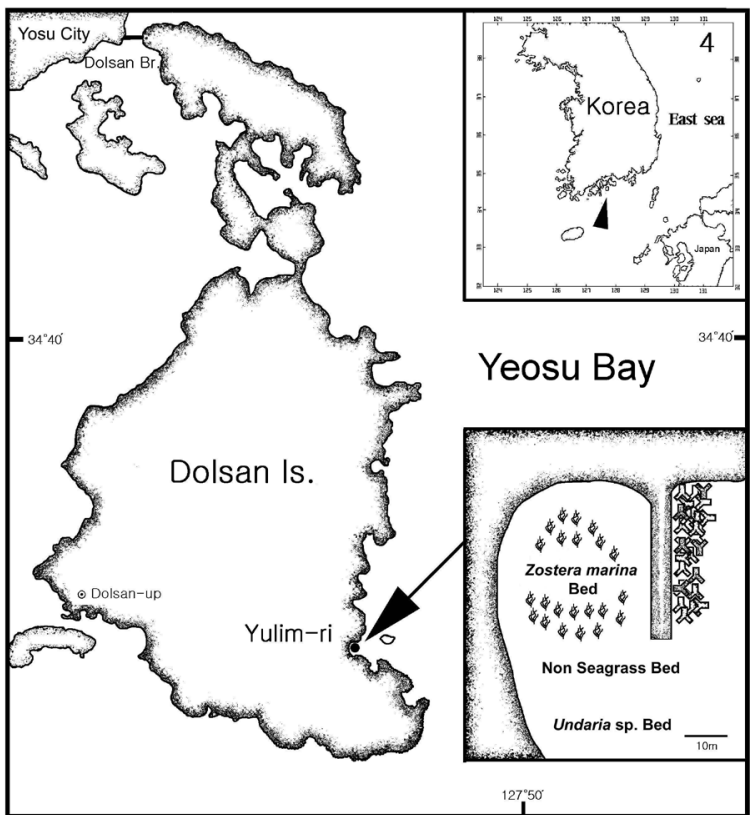

Fig. 1. A map showing the sampling site.

for epiphytic diatom research from the region of Yulimri $\left(34^{\circ} 36^{\prime} \mathrm{N}, 127^{\circ} 47^{\prime} \mathrm{E}\right)$ (Fig. 1), Yeosu City, Korea, in July 1998. The site has densely populated eelgrass beds, and is a small, semi-closed bay with narrow openings. Eelgrass sampling was carried out during ebb tide. The eelgrass samples were randomly collected in the upper $1 \mathrm{~cm}$ of sediments in a $10 \times 10 \mathrm{~cm}$ quadrate, and then refrigerated and moved to the laboratory (Heijs 1985, Moncreiff et al. 1992). The epiphytic diatoms on eelgrass were rinsed with distilled water, and removed with a nylon brush and a rubber knife. The collected epiphytic diatoms were cleaned with $\mathrm{HNO}_{3}$ and $\mathrm{H}_{2} \mathrm{SO}_{4}$, and mounted on cover slips for observing with SEM (TOPCON sm-300; Topcon, Co., Tokyo, Japan) as described previously (Hasle 1983).

The diameter of this species was measured on 50 frustules using Optimas V. 6.5 image analysis software (Media Cybernetics, Silver Spring, MD, USA). The valve structure elements were also measured using the software and as described previously (Genkal and Kiss 1993), using the formula:

$$
\tau=10 n / \pi D
$$

where $\tau$ is number of striae in $10 \mu \mathrm{m} ; n$, the number of striae on circumference of valve face; and $D$, the diameter of the valve. Terminology is according to Anonymous (1975) and Lee et al. (1995a).

Nutrient factors were measured by the method of Strickland and Parsons (1972), and water temperature and salinity was recorded using a YSI MODEL 33 SCT me- ter (Yellow Springs Instrument Co. Inc., Yellow Springs, $\mathrm{OH}, \mathrm{USA})$.

\section{RESULTS}

\section{Observation}

Cyclotella atomus var. marina Tanimura, Nagumo et Kato 2004

Present study Figs 2-21

Tanimura et al. (2004) Figs 3-15

Description: According to Håkansson (2002), Lowe (1975), and Servant-Vildary (1984), we describe in detail Cyclotella atomus var. marina.

The cells are solitary and disc-shaped. The valves are circular, flat, but those with a slight undulation can be found. The diameter of valves range from 3.1 to $3.4 \mu \mathrm{m}$.

The details of the central area, the marginal area, the mantle and the girdle band of the external view (Figs 2-7, Figs 18-21) are as follows. The central zone is smooth without any depressions and surrounded by striae. The striae (점무늬열) consist of 15 or 16 areola in $10 \mu \mathrm{m}$ and have a simple alveolate structure. Each alveolus (벌집구 멍) is opened externally by means of rows. In the marginal area, the fultoportulae (strutted process, 받침돌기) number 5 or 6 for every cell. The external pores of the fultoportulae range from 0.07-0.11 $\mu \mathrm{m}$ in diameter. Towards the mantle the regular rows gradually increase in number to 4-6 before reaching the margin of the shallow mantle. The striate zone has numerous granules toward the mantle. The girdle is composed of several bands, which are open (Figs 6, 7 \& 14-17).

The internal view with the central area, marginal area, the mantle fultoportulae with their satellite pores, the rimoportula (labiate process, 입술돌기) and the position (Figs 8-17) are as follows. The valve shows the alveoli, with one of the costae bearing the rimopotula and the costa bearing a fultoportula. The central area of the silica has no visible structure internally and extends over to nearly two-thirds the length of the costae and alveoli. The marginal fultoportulae are arranged at every second or third interstria with two satellite pores, and close to the mantle margin. They number 5 or 6 for every cell. The internal pores of the fultoportulae range from $0.14-0.18 \mu \mathrm{m}$. There is one marginal rimoportula per cell. This is situated on a recessed costa on the very short mantle in nearly the same or slightly over position as one of the fultoportulae, and is externally visible as an elongated opening. The 


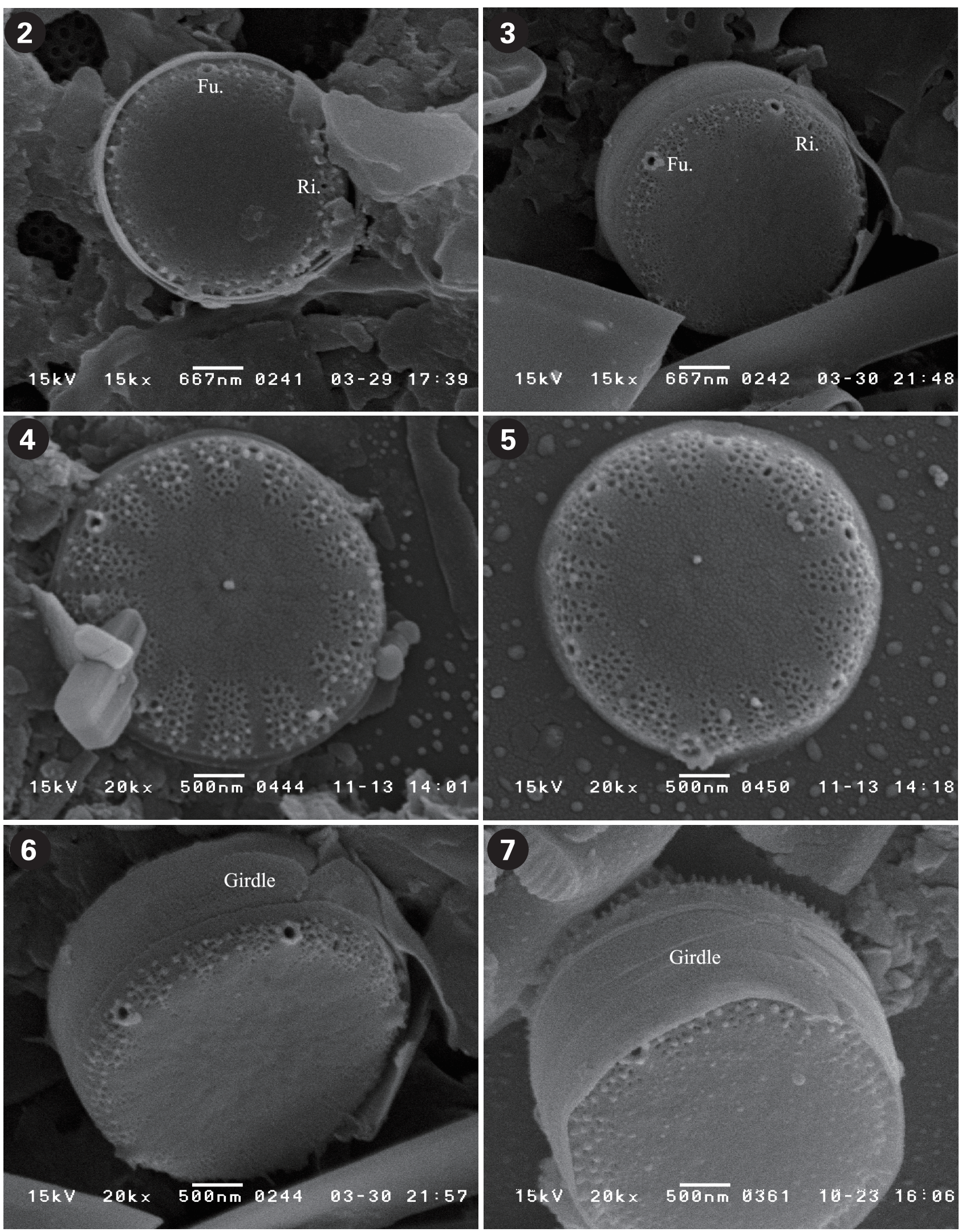

Figs 2-7. Cyclotella atomus var. marina SEM photos. Figs 2 \& 3. External view, showing marginal fultoportula (Fu.) and rimoportula (Ri.). Figs 4 \& 5. 3-4 rows areolae in each stria. Figs $6 \&$ 7. External girdle view, showing girdle folded in several bands. Each scale is shown in each photo. 

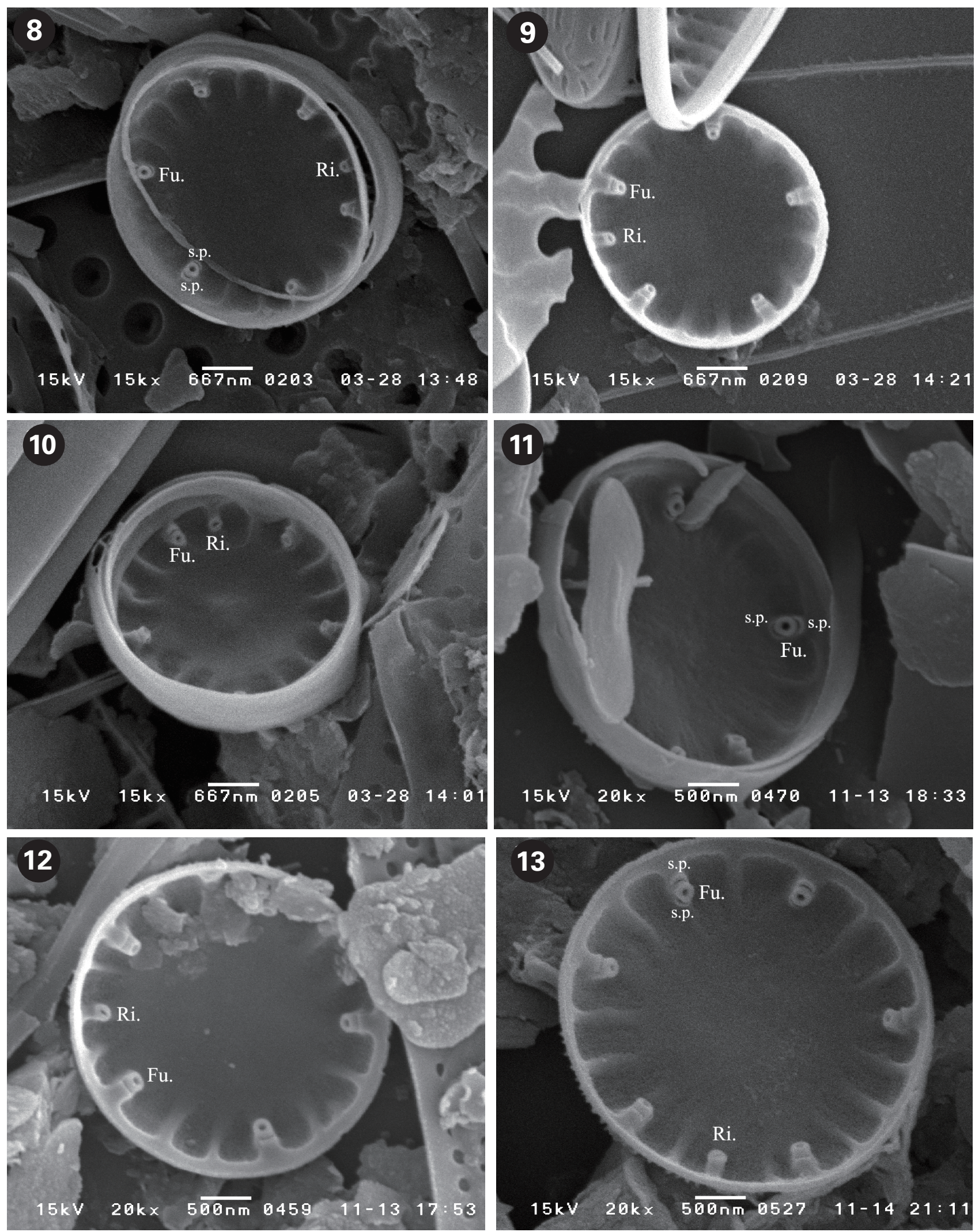

Figs 8-13. Cyclotella atomus var. marina SEM photos (Fu., Fultoportula; Ri., Rimoportula; s.p., satellite pore). Fig. 8. Six fultoportulae with two satellite pores arranged at every third cost, while one rimoportula is located beside one fultoportula. Figs 9-11. Five fultoportulae arranged at every third costa. Figs 12 \& 13. One rimoportula in the ring of fultoportulae. Each scale is shown in each photo. 

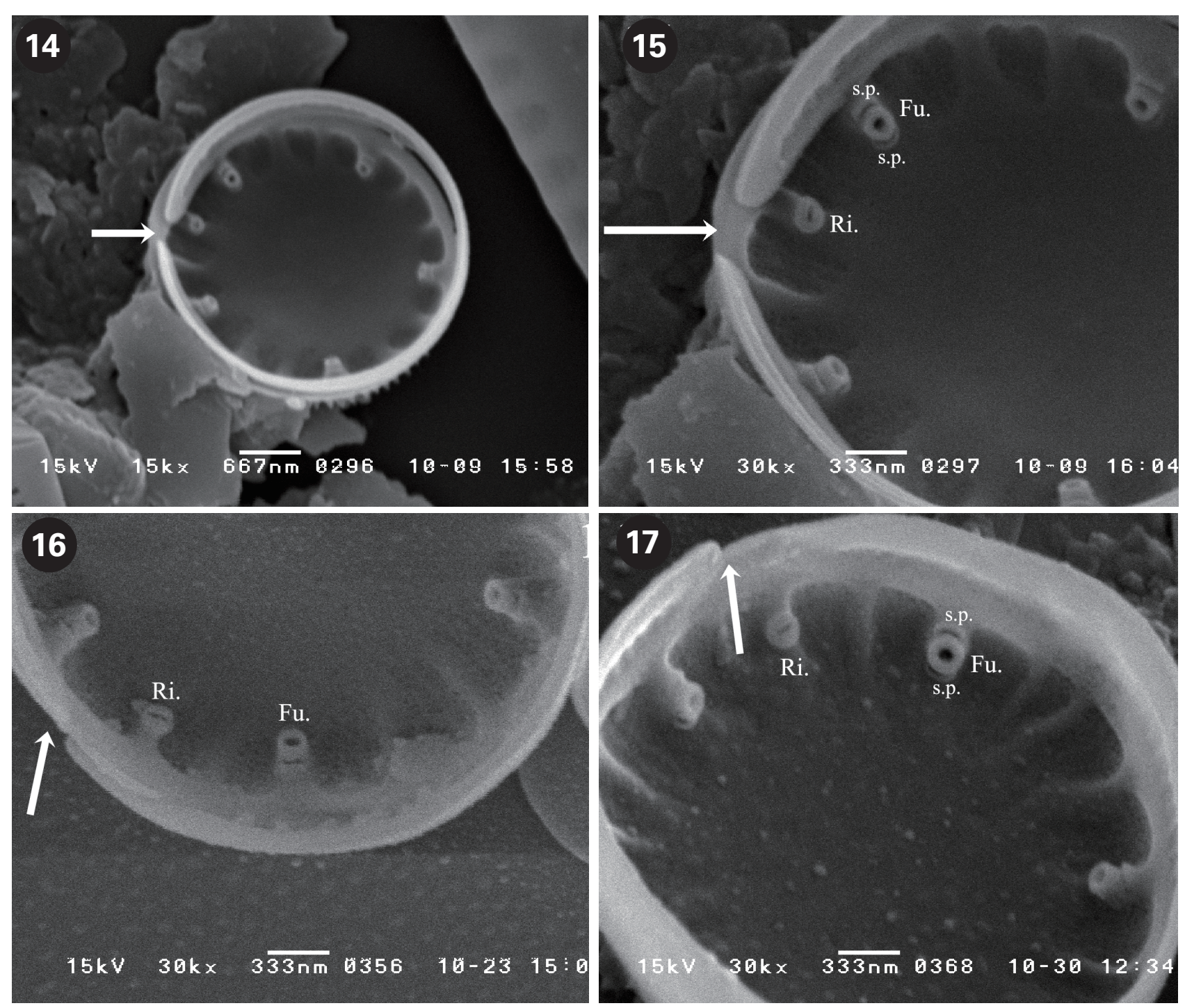

Figs 14-17. Cyclotella atomus var. marina SEM photos; intenal valve view. Fig. 14. Five fultoportulae and one rimoportula. Fig. 15. Details of Fig. 14, showing rimoportula (Ri.), fultoportula (Fu.) with two satellite pores (s.p.) and open girdle band (arrow). Figs 16 \&17. Rimoportula (Ri.), fultoportula (Fu.) with two satellite pores (s.p.) and open girdle band (arrow). Each scale is shown in each photo.

internal lips are small and vertical to the proximal costa.

Iconotypes: Figs 2-21 in the present study

Type locality: Yulim-ri, Dolsan Island of Yeosu, Korea

Habitat: metaphytic which means to be epiphytic or planktonic form, and abundant in marine waters around 26 psu salinity (Table 1).

\section{DISCUSSION}

A system of infrageneric classification of Cyclotella was initially proposed by Lowe (1975) and further extended by Servant-Vildary (1984). Apart from the criteria used by Lowe's classification, which are 1) presence and spacing of marginal fultoportulae, 2) presence and spacing of fultoportulae on the valve face, 3) presence and number of rimoportulae, 4) presence of spines, 5) other special features such as granulae and structure of striae, ServantVildary (1984) has further emphasized the importance of the structure of the alveoli. According to this diagnostic features proposed by Lowe and Servant-Vildary, we compared Cyclotella atomus var. marina with other species of Cyclotella (Table 2). All the compared species represent the following characteristics; a) a simple alveolus structure, b) presence of marginal rimoportula with simple internal lips, c) marginal fultoportula with simple external 

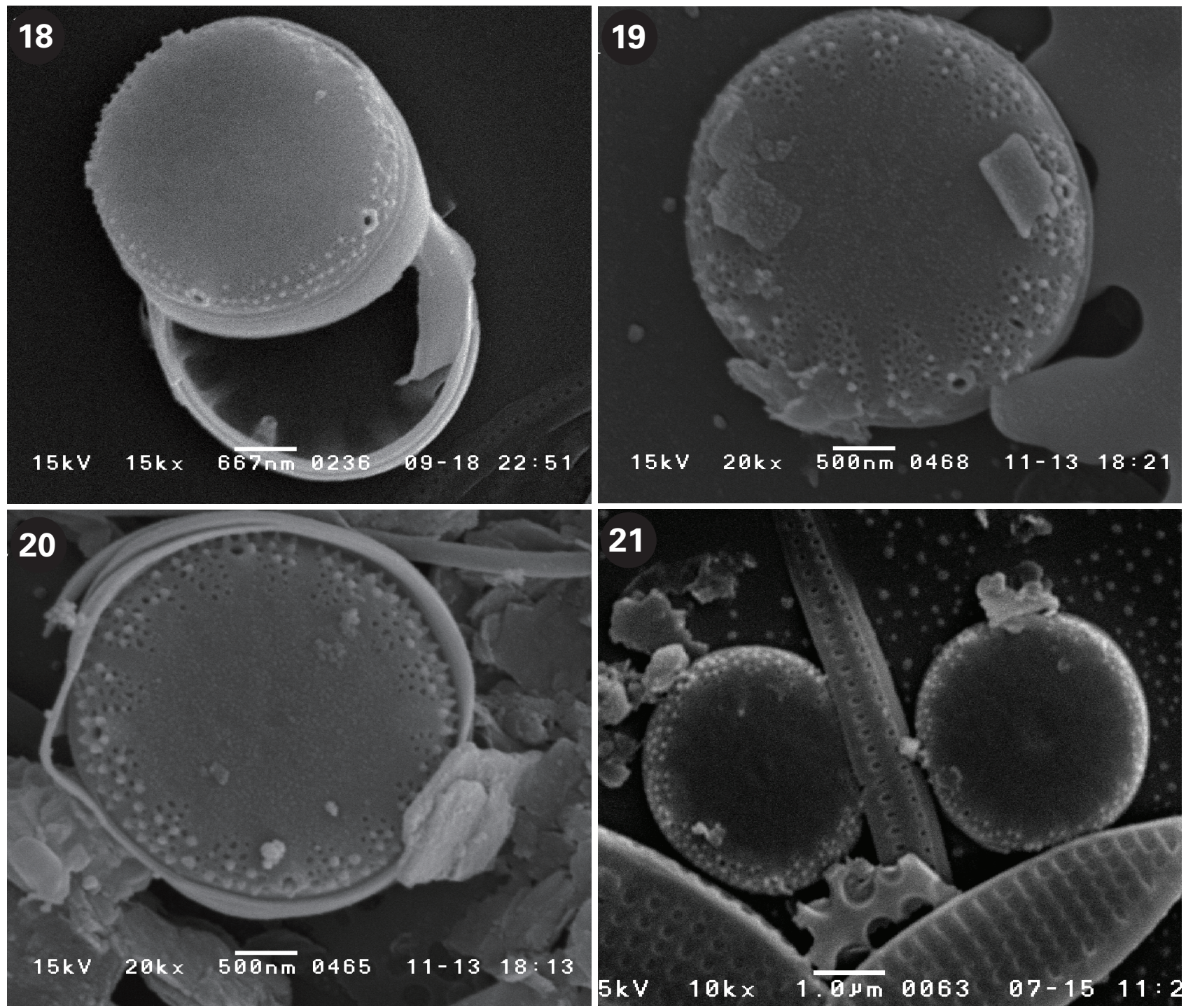

Figs 18-21. Cyclotella atomus var. marina SEM photos; showing various morphology of external valve. Each scale is shown in each photo.

and internal pores. C. atomus var. marina in this paper, $C$. atomus in Trigueros et al. (2000) (Figs 12-15), and C. atomus var. atomus in Genkal and Kiss (1993) (Fig. 13), have also similar fultoportulae, which have short tubes and the two satellite pores range parallel to the alveolae on the internal valve face. However, C. atomus var. marina in this paper differs from the other species in the absence of any central structure including pore, fultoportulae, and rimoportula. In contrast, C. atomus, C. atomus var. atomus and C. atomus var. gracilis have a central pore and fultoportulae.

In addition, it is very difficult to discern the morphological features in detail by light microscopy observation because of very small size. However, it can be seen that there is no fultoportula on the valve face and a simple al-
Table 1. The physico-chemical factors of the sampling site in July 1998

\begin{tabular}{|c|c|c|}
\hline Factors & Value & Range in $1998-1999^{a}$ \\
\hline $\mathrm{NO}_{2}(\mu \mathrm{M})$ & 26.99 & $0.09-26.99$ \\
\hline $\mathrm{NO}_{3}(\mu \mathrm{M})$ & 9.12 & $0.03-83.09$ \\
\hline $\mathrm{NH}_{4}(\mu \mathrm{M})$ & 1.14 & $1.14-93.61$ \\
\hline $\mathrm{PO}_{4}(\mu \mathrm{M})$ & 3.44 & $0.08-3.44$ \\
\hline $\mathrm{TN}(\mu \mathrm{M})$ & 37.25 & $6.62-134.26$ \\
\hline $\mathrm{SiO}_{2}(\mu \mathrm{M})$ & 1.18 & $0.10-3.87$ \\
\hline $\mathrm{p}-\mathrm{SiO}_{2}(\mu \mathrm{M})$ & 0.08 & $0.03-0.50$ \\
\hline Water temperature $\left({ }^{\circ} \mathrm{C}\right)$ & 23 & $8.5-28.3$ \\
\hline Salinity (psu) & 26 & $14.3-26.0$ \\
\hline
\end{tabular}

Taken from Chung (2003). 
Table 2. Comparison of diagnostic features between Cyclotella atomus var. marina and other varieties of Cyclotella atomus

\begin{tabular}{|c|c|c|c|c|c|}
\hline & $\begin{array}{l}\text { C. atomus var. } \\
\text { marina in the present } \\
\text { study }\end{array}$ & $\begin{array}{l}\text { C.atomus var. } \\
\text { marina in Tanimura } \\
\text { et al. (2004) }\end{array}$ & $\begin{array}{c}\text { C.atomus in } \\
\text { Håkansson and Clarke } \\
\text { (1997) }\end{array}$ & $\begin{array}{c}\text { C.atomus var. } \\
\text { atomus in Genkal and } \\
\text { Kiss (1993) }\end{array}$ & $\begin{array}{l}\text { C. atomus var. } \\
\text { gracilis in Genkal and } \\
\text { Kiss (1993) }\end{array}$ \\
\hline Habitat & Marine & Marine & Freshwater-brackish & Freshwater & Freshwater \\
\hline $\begin{array}{l}\text { Forms of } \\
\text { central area }\end{array}$ & $\mathrm{F}$ & $\mathrm{F}$ & F or SU & SU & SU \\
\hline $\begin{array}{l}\text { Diameter of } \\
\text { valves }(\mu \mathrm{m})\end{array}$ & $3.1-3.4$ & $3-4.5$ & $3.5-8.0$ & no data & $5.0-7.5$ \\
\hline $\begin{array}{l}\text { Central } \\
\text { fultoportula }\end{array}$ & $x$ & $x$ & $\circ$ & $\circ$ & $\circ$ \\
\hline $\begin{array}{l}\text { Marginal } \\
\text { fultoportula }\end{array}$ & ○ & $\circ$ & $\circ$ & $\circ$ & $\circ$ \\
\hline $\begin{array}{l}\text { Number of } \\
\text { satellite pore }\end{array}$ & 2 & 2 & $2-3$ & $2-3$ & $2-3$ \\
\hline $\begin{array}{l}\text { Marginal } \\
\text { rimoportula }\end{array}$ & ० & ० & $\circ$ & $\circ$ & ० \\
\hline
\end{tabular}

F, Flat; SU, Slightly undulated.

veolate structure at the margin.

The cell structure and size of $C$. atomus var. marina in this paper are similar to only C. atomus var. marina reported by Tanimura et al. (2004). Both have a similar size, a number of marginal fultoportula and rimoportula, and do not have any central structure.

C. atomus var. marina was first recorded by Tanimura et al. (2004) in Tokyo Bay, Japan. This species grows abundantly at a salinity of around 30 psu salinity and is abundant in water with higher nutrients, such as in bays. The presently-described C. atomus var. marina was also found in nutrient-rich marine waters (Table 1).

C. atomus var. marina described in this study was found among epiphytic diatom on eelgrass, but Tanimura et al. (2004) reported this species in the water column of Tokyo Bay. Actually, it seems to be not a true epiphyta because we could not find any attaching material. This species may not be a true epiphyic, but rather a metaphytic diatom that exists in both benthic and/or planktonic forms (Håkansson personal communication).

According to this ecological and morphological evidence, we believe that the species in the present study is identical with the C. atomus var. marina described as a new variety by Tanimura et al. (2004). This is the first report of this species in Korean waters.

\section{ACKNOWLEDGEMENTS}

This study was supported by 'The survey of Indigenous Biology of Korea' from National Institute of Biological Re- sources (NIBR) of Repubic of Korea, and also by Jellyfish bloom project from National Fisheries Research and Development Institute (NFRDI) to M.H. Chung.

\section{REFERENCES}

Anonymous. 1975. Proposals for a standardization on diatom terminology and diagnoses. Nova Hedwigia Beih. 53:323-354.

Brébisson, A. D. E. 1838. Considerations sur les diatomees et essai d'une classification des genres et des especes appartenant a cette famille. Bree 1'Aine Imprimeur Libraire, Falaise, 22 pp.

Chang, T. P. \& Steinberg, C. 1988. Epiphytische diatomeen auf Cymatopleura und Nitzschia. Diatom Res. 3:203-216.

Cho, K. J. 1996. Fine morphology of some Cyclotella species from the freshwater zone of the Naktong River. Algae 11:9-21.

Choi, J. K. 1990. A checklist of marine tychopelagic and benthic diatoms in Korea. Korean J. Phycol. 5:73-116.

Chung, M. H. 2003. Ecological and taxonomical characteristics of epiphytic diatom on seagrasses in Korea. Ph.D. dissertation, Hanyang University, Seoul, Korea, 150 pp.

Genkal, S. I. \& Kiss, K. T. 1993. Morphological variability of the diatom Cyclotella atomus Hustedt var. atomus and $C$. atomus var. gracilis var. nov. Hydrobiologia 269/270:3947.

Håkansson, H. 2002. A compilation and evaluation of species in the general Stephanodiscus, Cyclostephanos and Cyclotella with a new genus in the family Stephanodiscaceae. Diatom Res. 17:1-139.

Håkansson, H. \& Clarke, K. B. 1997. Morphology and tax- 
onomy of the centric diatom Cyclotella atomus. Nova Hedwigia 65:207-219.

Håkansson, H., Hajdu, S., Snoeijs, P. \& Loginova, L. 1993. Cyclotella hakassoniae Wendker and its relationship to $C$. caspia Grunow and other similar brackish water Cyclotella species. Diatom Res. 8:333-347.

Hasle, G. R. 1983. Notebook of international phytoplankton taxonomy course; a guide to marine plankton diatoms. University of Oslo, Oslo, 55 pp.

Hasle, G. R. \& Syvertsen, E. E. 1997. Marine diatom. In Thomas, C. R. (Ed.) Identifying Marine Phytoplankton. Academic press, New York, pp. 5-385.

Heijs, F. M. L. 1985. The seasonal distribution and community structure of the epiphytic algae on Thalassia hemprichii (Ehrenb.) Aschers. from Papua New Guinea. Aquat. Bot. 21:295-324.

Kützing, F. T. 1833. Synopsis diatomacearum oder versuch einer systematischen zusammenstellung der diatomeen. Linnaea 8:529-620.

Lee, J. H. \& Lee, E. H. 1988. A taxonomic study on the genus Cyclotella, Bacillariophyceae, in Korea water. Korean J. Phycol. 3:133-145.

Lee, J. H., Kim, H. S., Park, C. W. \& Chung, J. 1994. Morphological study of Cyclotella pseudostelligera Hust. (Bacillariophyceae). Korean J. Phycol. 9:111-114.

Lee, J. H., Lee, K. \& Choi, J. K. 1995a. Taxonomic studies on diatoms in Korea. III. Koreanization of terminology. Korean J. Phycol. 10(Suppl):91-118.

Lee, K., Choi, J. K. \& Lee, J. H. 1995b. Taxonomic studies on diatoms in Korea. II. Check-list. Korean J. Phycol. 10(Suppl):13-89.
Lowe, R. L. 1975. Comparative ultrastructure of the valves of some Cyclotella species (Bacillariophyceae). J. Phycol. 11:415-424.

Moncreiff, C. A., Sullivan, M. J. \& Daehnick, A. E. 1992. Primary production dynamics in seagrass beds of Mississippi sound: the contributions of seagrass, epiphytic algae, sand microflora, and phytoplankton. Mar. Ecol. Prog. Ser. 87:161-171.

Servant-Vildary, S. 1984. Fossil Cyclotella species from Miocene Lacustrin deposit of Spain. In Ricard, M. (Ed.) Proc. 8th Int. Diatom Symp., Koeltz, Koenigstein, pp. 495-511.

Strickland, J. D. H. \& Parsons, T. R. 1972. A practical handbook of seawater analysis. 2nd ed. Fishery Reserch Board, Ottawa, $311 \mathrm{pp}$.

Sullivan, M. J. 1982. Community structure of epiphytic diatoms from the Gulf coast of Florida, U.S.A. In Mann, D. G. (Ed.) Proc. 7th Int. Diatom Symp., Koelts, Koenigstein, pp. 373-384.

Tanimura, Y., Nagumo, T. \& Kato, M. 2004. A new variety of Cyclotella atomus from Tokyo Bay, Japan; C. atomus var. marina var. nov. Bull. Natl. Sci. Mus. Ser. C 30:5-11.

Trigueros, J. M., Ansotegui, A., Orive, E. \& Nó, M. L. 2000. Morphology and distribution of two brackish diatoms (Bacillariophyceae): Cyclotella atomus Hustedt and Thalassiosira guillardii Hasle in the estuary of Urdaibai (northern Spain). Nova Hedwigia 70:431-450.

van Landingham, S. L. 1969. Catalogue of the fossil and recent genera and species of diatoms and their synonyms. Part III. Coscinophaena through Fibula. Lubrecht \& Cramer, Lehre, pp. 1087-1756. 